\title{
ANALISIS PENGARUH PROJECT COST MANAGEMENT DAN STANDARD MARKUP PRICING SEBAGAI STRATEGI BERKEMBANG BUKIT GRHADIKA GARDEN AGRO EDUWISATA DI MASA PANDEMI
}

\author{
Indra Trisna Septiawan ${ }^{1}$, Endang Kartini Panggiarti ${ }^{2}$ \\ 1,2 \\ Jurusan Akuntansi Fakultas Ekonomi Universitas Tidar \\ E-mail: ${ }^{1)}$ Krisnarevan24@gmail.com, ${ }^{2)}$ endangkartini@untidar.ac.id
}

\begin{abstract}
Penelitian ini merupakan salah satu upaya untuk menganalisis strategi yang digunakan oleh objek penelitian yaitu Bukit Grhadika Garden Agro Eduwisata untuk dapat bertahan di masa pandemi. Penelitian ini termasuk penelitian kualitatif dengan pendekatan deskriptif. Metode pengumpulan data yang digunakan adalah wawancara terhadap subjek penelitian untuk mendapatkan informasi yang valid serta akurat serta dilengkapi dengan data sekunder. Penelitian ini merupakan analisis terhadap pengaruh strategi Project Cost Management dan Standard Markup Pricing untukmenekan biaya agar bisa terus bertahan di masa pandemi. Hasil yang diperoleh adalah strategi yang digunakan yaitu Project Cost Management dan Standard Markup Pricing berdampak positif bagi perkembangan Bukit Grhadika Garden Agro Eduwisata di masa pandemi. Strategi Project Cost Management yang dilakukan untuk melakukan pengembangan Agro Eduwisata sangat berpengaruh baik bagi pembangunan dan perbaikan tempat wisata yang lebih menarik bagi calon pengunjung meski di masa pandemi, sejalan dengan itu pemasaran wisata melalui media online yang dilakukan untuk memperkenalkan spot wisata baru ternyata cukup menarik dan menaikkan jumlah wisatawan. Kemudian Standard Markup Pricing juga membuat pengunjung lebih tertarik. Penelitian ini menyimpulkan bahwa strategi bisnis yang dilakukan pengelola Bukit Grhadika Garden Agro Eduwisata berhasil mempertahankan eksistensinya meskipun di masa pandemi.
\end{abstract}

Kata Kunci: Project Cost Management, Standard Markup Pricing, Agro Eduwisata, Strategi Bisnis

\begin{abstract}
This study aims to assess the approach employed by the research object, namely Bukit Grhadika Garden Agro Eduwisata, in order to survive the pandemic. This is a qualitative study employing a descriptive approach. Interviews with study subjects are used to elicit reliable and accurate information, which is supplemented by secondary data. This research examines the effect of Project Cost Management and Standard Markup Pricing strategies on cost reductions necessary to survive the pandemic. The findings revealed that the measures employed, namely Project Cost Management and Standard Markup Pricing, had a positive influence in the development of Bukit Grhadika Garden Agro Eduwisata during the pandemic. The Project Cost Management strategy used to develop Agro Edutourism has a significant impact on the development and improvement of tourist attractions that are more appealing to potential visitors, even during a pandemic. In addition, tourism marketing via online media is quite attractive and helps increase the number of tourists. Additionally, Standard Markup Pricing increases visitor interest as well. This study finds that the management of Bukit Grhadika Garden Agro Eduwisata's business strategy enabled the company to survive the pandemic.
\end{abstract}

Keywords: Project Cost Management, Standard Markup Pricing, Agro Edutourism, Business Strategy 


\section{PENDAHULUAN}

Coronavirus disease (Covid-19) merupakan penyakit yang menular dimana penyakit ini disebabkan oleh virus corona yang menyerang pernafasan manusia. Covid-19 ini menyebabkan penyakit dari penyakit ringan hingga serius sampai pada kematian. Pertama kalinya virus ini menyebar di wuhan, Tiongkok pada bulan Desember 2019 tahun lalu. Virus ini menyebar di berbagai belahan dunia (WHO, 2020). Sedangkan di Indonesia virus ini mulai menyebar pada bulan maret 2020 (Dwina, 2020). Akibat dari adanya masa pandemic ini berdampak pada hampir semua sektor yang ada mulai dari perkenomian, pendidikan dan lainnya.

Sektor perekonomian menjadi lemah atau mengalami penurunan dengan adanya pandemic covid-19. Berkaitan dengan perekonomian, yang menjadi salah satu faktor yang mendorong peningkatan perekonomian di Indonesia adalah Pariwisata. Sektor pariwisata merupakan faktor yang penting dimana peningkatan yang muncul berkaitan dengan peningkatan pendapatan, penciptaan lapangan pekerjaan dan pengembangan usaha serta peningkatan infrastruktur (Putra \& Afri, 2020) Akan tetapi dengan adanya pandemic ini banyak pusat perbelanjaan dan tempat wisata tutup, ha ini untuk meminimalisir virus covid19 menyebar secara luas.

New normal merupakan kebijakan yang diambil oleh pemerintah sebagai upaya untuk mengatasi adanya dampak dari pandemic-19, dimana New Normal merupakan perubahan tatanan kehidupan yang ada dalam masyarakat dengan kebiasaan baru. Pariwisata mulai dibuka kembali setelah adanya New Normal dengan menerapkan protokol kesehatan guna mencegah penyebaran virus Covid-19 ini (Aditya, 2020).

Harga jual merupakan sejumlah uang untuk mendapatkan barang ataupun jasa atau jumlah yang ditukarkan konsumen atas manfaat dengan dimilikinya atau digunakanya produk atau jasa tersebut. Dalam penentuan harga jual yang dapat mengambil keputusan adalah pihak manajemen. Dalam penentuan harga terdapat beberapa metode yaitu cost plus pricing method, mark up price method, dan penentuan harga oleh produsen. Mark up price method merupakan jumlah rupiah yang ditambahkan pada biaya dari suatu produk untuk menghasilkan harga jual. Penentuan markup ini di peroleh dari presentase biaya produk atau harga jualnya (Toar et al., 2017).

\section{LANDASAN TEORI}

\subsection{Masa Pandemi Covid-19}

Dari data WHO, Covid-19 pertama kali muncul di Wuhan, Tiongkok pada Desember 2019. Coronavirus disease (Covid-19) ini merupakan virus baru yang menyerang manuasia maupun hewan. Virus ini menyebabkan gangguan pernafasan pada manusia seperti batuk, pilek hingga Middle East Respirator Syndrome (MERS) atau Severe Acute Respiratory (SARS). Virus ini merupakan virus yang dapat menular dan menyerang manusia dengan cepat. Virus ini dapatmenyerang manusia lewat cairan atau tetesan melalui mulut atau hidung. Cairan dari orang yang terinfeksi apabila menempel pada sebuah benda. Orang yang bersalam atau memegang benda yang terinfeksi virus dapat terancam terinfeksi juga sehingga diaharuskan pencegahan pada diri sendiri.

Virus Covid-19 ini menyebar di seluruh dunia, tak terkecuali Indonesia. Virus ini di konfirmasi mulai masuk di Indonesia oleh pemerintah pada bulan Maret 2020 akan tetapi 
Virus Covid-19 ini sebenarnya sudah masuk pada awal bulan Januari di Indonesia hal ini di katakan oleh Pakar Epidemiologi Universitas Indonesia (UI) Pandu Riono "Sejak awal Januari kemungkinan besar virus (Sars-VoV-2) itu sudah masuk ke Indonesia" (Pranita \& Nursastri, 2020).

Masa Covid-19 ini merubah tatanan yang ada dalam masyarakat salah satunya sektor perekonomian. Masa pandemic ini terus menerus meningkat dalam penyebarannya sehingga untuk mencegah dan meminimalkan penyebaran virus ini berbagai peraturan dikeluarkan oleh pemerintah salah satunya pembatasan sosialisasi yaitu Pembatasan Sosial Berskala Besar (PSBB) (benony Walakula, 2020). Akan tetapi seiring dengan berjalannya waktu sistem ini sangat mempengaruhi perkembangan atau kesimbangan perekonomian Indonesia, maka pemerintah melonggarkan kebijakan pembatasan ini dengan mengimplementasikan masa $\mathrm{New}$ Normal.

\subsection{Dampak Sektor Pariwisata}

Indonesia merupakan salah satu Negara yang terkenal akan sektor Pariwisatanya. Banyak daerah Indonesia yang menjadi tujuan wisatadari Maluku, Bali dan masih banyak lagi. Tempat wisata ini menjadi sumber devisa negara, peningkatan penciptaan lapangan pekerjaan, kegiatan produksi, dan pendapatan nasional, pertumbuhan sektor swasta dan pembangunan infrastruktur (benony Walakula, 2020). Masa Pandemi Covid-19 berdampak pada perekonomian salah satunya di sektor pariwisata. Hal ini berkaitan dengan banyak Negara yang menghentikan wisata antar Negara. Pariwisata mengalami penurunan akan tetapi dengan adanya pemberlakuan New Normal sektor pariwisata mulai bangkit kembali. Meskipun sudah ada pemberlakuan masa new normal sektor pariwisata ini mengalami dilemma dimana bagaimana meningkatkan produktifitas dengan meminimalkan penularan / penyebaran covid-19 yang munngkin dapat terjadi bila wisatawan yang berkunjung banyak. (Gunagama et al., 2020).

Muncul isu perjalanan balas dendam atau yang diseburt revenge travel dimana orangorang akan berwisata setelah melalui karantina dan pembatasan sosialisasi. Sehinga hal ini dapat meningkatkan atau mengembalikan pariwisata yang ada (Gunagama et al., 2020). Di masa new normal ini para pemangku kepentingan pariwisata mulai berinovasi dan menungkan kreatifitasnya guna mengembalikan sektor pariwisata yaitu dengan beberapa hal sebagai berikut:

a) Perlunya perubahan yang signifikan terhadap Objek Daya Tarik Wisata dalam hal ini sektor pariwisata dapat mempersiapkan pemecahan massa dimana terdapat jenis nonmassal dan pariwisata terbatas. Kunjungan bersifat individu atau kelompok selain itu adanya model paket wisata.

b) Adanya anjuran dari WHO untuk meminimalkan penyebaran virus Covid-19 ini memunculkan inovasi wisata digital.

\subsection{Bukit Grhadika Garden Agro Eduwisata}

Lokasi Bukit Grhadika Garden Agro Eduwisata berada di Dusun Kobar, Kalirejo, Kec. Salaman, Magelang, Jawa Tengah 56162. Rute menuju Bukit ini bisa ditempuh dari kota Magelang dengan menuju arah Purworejo. Berjarak sekitar $20 \mathrm{~km}$ dari Kota Magelang dan membutuhkan waktu perjalanan sekitar 30 menit. Jam Buka/Jam Operasional Bukit Sanjaya Selo dibuka mulai pukul 05.30 hingga 17.30 WIB pada setiap harinya. 


\subsection{Manajemen biaya (Project Cost Manajement)}

Manajemen biaya (Project Cost Manajement) adalah sebuah metode yang menggunakan teknologi untuk mengukur biaya dan produktivitas melalui siklus hidup penuh proyek tingkat perusahaan. Fungsi khusus manajemen proyek yang mencakup kontrol pekerjaan memperkirakan, pengumpulan data lapangan, penjadwalan, akuntansi dan desain. Dimulai dengan memperkirakan, alat vital di Project Cost Manajement, data historis aktual digunakan untuk merencanakan secara akurat semua aspek proyek. Karena proyek akan terus berlanjut, kontrol pekerjaan menggunakan data dari estimasi dengan informasi yang dilaporkan dari lapangan digunakan mengukur biaya dan produksi yang ada dalam suatu proyek. Dari inisiasi proyek sampai selesai, proyek manajemen biaya memiliki tujuan untuk menyederhanakan dan murahnya pengalaman proyek.

Pengertian Cost / Biaya merupakan semua sumber daya yang harus dikorbankan guna mencapai tujuan spesifik / untuk mendapat sesuatu sebagai gantinya. Biaya ini pada umumnya dapat diukur dalam satuan keuangan seperti dollar, rupiah, atau lainnya Project Cost Management / Manajemen Biaya Proyek merupakan proses yang dibutuhkan untuk menjamin bahwa proyek dapat diselesaikan sesuai dengan budget yang telah disepakati.

Tahapan Biaya Manajemen Proyek terdiri dari 3:

a) Cost estimating

Cost estimating melibatkan pengembangan suatu perkiraan atau estimasi biaya dari resource yang dibutuhkan untuk menyelesaikan suatu proyek. Project manager harus menentukan estimasi biaya dengan teliti jika ingin menylesaikan proyek dengan batasan biaya yang ada. Secara normal project manajer mempersiapkan beberapa tipe dari cost estimate untuk banyak proyek, yaitu Rough Order Magnitude (ROM) estimate, Budgetary estimate, dan Definitive estimate. Cost management plan adalah suatu dokumen yang menggambarkan bagaimana organisasi akan mengatur perbedaan biaya dalam proyek.

b) Cost budgeting

Cost budgeting merupakan pengalokasian estimasi biaya untuk pekerjaan perorangan dalam setiap waktu. Pekerjaan tersebut didasari pada WBS proyek yang dikerjakan. Tujuan utama dari cost budgeting adalah untuk menghasilkan suatu cost baseline untuk memastikan performa proyek dan kebutuhan proyek. Suatu cost baseline adlah suatu tahapan waktu dari budget yang digunakan oleh project manager untuk memastikan dan memantau penggunaan biaya. Cost budgeting juga menyediakan informasi untuk pembiayaan kebutuhan.

c) Cost control

Project cost control ini termasuk pemantauan penggunaan biaya, dan memastikan hanya perubahan proyek yang sesuai yang dimasukkan dalam suatu cost baseline yang telah ditinjau kembali dan menginformasikan stakeholder mengenai perubahan proyek yang disahkan yang akan mempengaruhi biaya. Cost baseline, performace report, perubahan yang diinginkan, dan pembiayaan kebutuhan proyek merupakan input untuk proses cost control (Cahyono, 2017).

\subsection{Standard Mark Up Pricing}

Standard Mark Up Pricing atau metode penentuan harga suatu harga dapat terbentuk dipasar sebagai interaksi jumlah penawaran dan permintaan. Meskipun biaya bukan satu- 
satunya faktor yang menentukan harga jual memberikan informasi biaya penuh untuk menghitung konsekuensi laba dari setiap alternative harga jual yang ada dipasar. Salah satu metode yang dapat dipakai dalam menentukan harga jual yaitu Penentuan Harga Jual dalam Keadaan Normal, dimana metode penentuan harga jual (Cost Plus Pricing) merupakan harga jual yang ditentukan dengan menambah biaya masa yang akan datang dengan suatu persentase mark up.

Mark up disini besarnya sama dengan biaya tidak langsung ditambah dengan laba yang diharapkan. Harga jual berdasarkan cost plus pricing memperhitungkan dua unsur yaitu taksiran biaya penuh dan juga laba yang diharapkan. Apabila biaya dipakai sebagai dasar penentuan harga jual baik dalam pendekatan full costing maupun variabel costing, biaya penuh dapat dibagi menjadi dua yaitu biaya yang dipengaruhi langsung oleh volume produksi dan biaya yang tidak dipengaruhi langsung oleh volume produksi. Biaya ini dapat ditambahkan pada laba yang diharapkan untuk perhitungan persentase mark up (Handoyo: 2007).

\section{METODE PENELITIAN}

Penelitian ini merupakan penelitian kualitatif dengan metode wawancara yang menggunakan pendekatan deskriptif. Wawancara dilakukan untuk mendapatkan data primer dari narasumber sebagai bahan untuk menganalisis hipotesis. Metode kualitatif yang digunakan adalah pengumpulan data di tempat objek penelitian yaitu Bukit Grhadika Garden Agro Eduwisata, yang bermaksud untuk mengamati dan menganalisis pengaruh Bugdet Cost dan Standard Markup Pricing sebagai strategi mengatasi dampak pandemi terhadap kegiatan bisnis yang dijalankan

Analisis deskriptif digunakan untuk menggambarkan fenomena yang sedang terjadi saat ini dan yang telah terjadi di masa lampau. Harapannya, dengan metode ini dapat diperoleh informasi untuk membantu menganalisis pengaruh dari fenomena yang terjadi dan strategi yang digunakan sebagai solusi.

Dalam metode ini, terdapat dua sumber informasi dan data, yaitu primer dan sekunder. Subjek penelitian menjadi sumber data yang utama, sedangkan data pendukung lainnya diperoleh dengan menggunakan studi literatur. Pemilihan subjek penelitian adalah pengelola Bukit Grhadika Garden Agro Eduwisata yang menjadi sumber data primer.

\section{HASIL DAN PEMBAHASAN}

Berdasarkan data yang diperoleh dari narasumber, dijelaskan beberapa pengaruh strategi dalam pertahanan bisnis dimasa pandemic sehingga dapat membantu perkembangan bisnis, diantaranya:

1. Strategi Project Cost Budgeting digunakan oleh pengelola untuk melaksanakan pembangunan dimasa pandemi, terlebih saat awal masa pandemi. Sedikitnya wisatawan yang berkunjung membuat pembangunan dapat dilakukan secara intensif di awal masa pandemi. Kemudian strategi yang dilakukan pada kuartal tahun ke II 2020 adalah dengan membuka secara luas Agro Eduwisata ini, pada hari libur sebelum beroperasi setiap hari. Hal tersebut sebagai upaya tetap mematuhi anjuran pemerintah tentang pembatasan 
sosial, serta untuk terus dapat melakukan pembangunan dengan tujuan semakin membuat pengunjung nyaman dan serta memperindah dan melengkapi fasilitas agar tertarik untuk datang. Dengan hal tersebut, strategi pembiayaan berfokus pada pengelolaan dan pembangunan sarana dan prasarana yang memanfaatkan dana hasil pendapatan selama masa operasional di hari libur. Setelah dibuka secara massif, Agro Eduwisata ini mempunyai misi baru yaitu dengan menambahkan fasilitas dibawah bukit berupa gazebo, dan sebagainya agar wisatawan betah serta merasa nyaman. Project Cost Budgeting sebagai metode biaya pembangunan ditekankan pada biaya pekerja dan alokasi waktu pengerjaan. Penekanan biaya dilakukan dengan memanfaatkan laba hasil operasional sebagai tambahan modal untuk kelancaran pembangunan. Cost estimating dilakukan dengan mengasumsikan bahwa tiket operasional yang dibebankan kepada pengunjung termasuk kedalam biaya sumbangan pembangunan yang mampu menekan biaya pengembangan Agro Eduwisata. Pengerjaan pengembangan memberdayakan para pemuda pengelola yang menekan biaya tenaga kerja. Strategi Project Cost Budgeting digunakan dalam penentuan alokasi waktu dan estimasi biaya sesuai dengan jadwal pekerjaan dan presentasi pengembangan yang diharapkan.

2 Standard Markup Marketing yang digunakan adalah untuk menentukan biaya tiket masuk. Didalam biaya tiket masuk yang dibebankan kepada pengunjung termasuk biaya pengembangan dan biaya yang dibedakan berdasarkan usia. Walaupun tertera dalam promosinya bahwa harga tiket senilai Rp 5.000 namun pada operasionalnya pembebanan biaya kepada wisatawan anak relative lebih kecil. Kemudian, penggantian tiket dengan air minum merupakan strategi untuk meningkatkan minat wisatawan dan dipromosikan sebagai tiket masuk yang sebenarnya sangat bermanfaat bagi pengunjung, karena naik ke atas bukit cukup melelahkan. Strategi ini menarik pengunjung untuk datang lagi dengan berbagai insentif yang ditawarkan, tanpa menyadari bahwa pengunjung juga ikut berkontribusi dalam upaya pengembangan Agro Eduwisata.

\section{KESIMPULAN}

Penelitian ini memiliki keterbatasan ruang lingkup dan narasumber. Harapan kedepan bahwa penelitian ini mampu menjadi acuan untuk penelitian berikutnya yang mampu mengembangkan pengaruh positif dari Project Cost Management dan Standard Markup Pricing sebagai strategi pengembangan bisnis. Pengelola menyatakan bahwa strategi yang digunakan dalam Agro Eduwisata ini telah mampu membuat objek wisata ini bertahan selama pandemi. Hal ini dapat dilihat dari strategi bisnis yang dilakukan, dalam Strategi Project Cost Management telah dilakukan upaya dengan cara membangun dan memperbaiki tempat wisata agar lebih menarik minat calon pengunjung, disamping itu juga dilakukan pemasaran secara online melalui sosial media/media online untuk memperkenalkan spot wisata baru dan sebagai hasilnya yaitu jumlah wisatawan meningkat. Dalam strategi Standard Markup Pricing yakni dengan mebebankan biaya tiket masuk sesuai usia dan penggantian tiket dengan air minum ternyata berhasil membuat pengunjung lebih tertarik. Oleh karena itu, diharapkan semoga strategi ini kedepannya juga dapat diterapkan oleh Agro Eduwisata yang lain agar mampu membantu pemulihan perekonomian. 


\section{DAFTAR PUSTAKA}

Aditya, N. R. (2020). Yogyakarta Siap Buka Pariwisata, Wisatawan Diminta Patuhi Protokol New Normal. Jakarta. Retrieved from Travel. Kompas. Com.

benony Walakula, Y. (2020). Analisis Eksistensi Pariwisata Indonesia di Tengah Situasi Pandemi Corona Virus Disease (Covid19). Jurnal Ilmu Sosial Keagamaan Institut Agama Kristen Negeri Ambon, 1(1).

Cahyono, D. (2017). Project Cost Management. https://dwicah13.wordpress.com/2012/03/27/project-cost-management/

Dwina, I. (2020). Melemahnya ekonomi indonesia pada sektor pariwisata, akibat dampak dari pandemi covid-19.

Gunagama, M. G., Naurah, Y. R., \& Prabono, A. E. P. (2020). Pariwisata Pascapandemi: Pelajaran Penting dan Prospek Pengembangan. LOSARI: Jurnal Arsitektur Kota Dan Pemukiman, 56-68.

Pranita, E., \& Nursastri, S. A. (2020). Diumumkan Awal Maret, Ahli: Virus Corona Masuk Indonesia dari Januari. Kompas. Com.

Putra, S. H., \& Afri, E. (2020). Pemanfaatan Sistem Informasi Geografis Dalam Pengembangan Pariwisata Di Kawasan Wisata Kabupaten Langkat. Prosiding Seminar Nasional Riset Information Science (SENARIS), 2, 271-277.

Toar, O., Karamoy, H., \& Wokas, H. (2017). Analisis perbandingan harga jual produk dengan menggunakan metode cost plus pricing dan mark up pricing pada dolphin donuts bakery. Jurnal EMBA: Jurnal Riset Ekonomi, Manajemen, Bisnis Dan Akuntansi, 5(2).

WHO. (2020). Coronavirus disease (COVID-19). https://www.who.int/emergencies/diseases/novel- coronavirus-2019/question-andanswers-hub/q-a-detail/coronavirus-disease- covid-19 
